\title{
Monitoring Detak Jantung untuk Atlet Lari 100 Meter Berbasis Internet of Things
}

\author{
Muhammad Aksa Hidayat ${ }^{1, \mathrm{a}}$ Sritrusta Sukaridhoto ${ }^{2, \mathrm{~b}}$ Achmad Basuki ${ }^{2, \mathrm{c}}$ Muhammad Fajrul Falah ${ }^{2, \mathrm{~d}}$ \\ ${ }^{1}$ Politeknik Negeri Fakfak, Manajemen Informatika, Jalan Imam Bonjol Atas, Air-Merah Wagom \\ ${ }^{2}$ Politeknik Elektronika Negeri Surabaya, Kampus Pens, Jl.Raya ITS, Sukolilo, Kota SBY, Jawa Timur 60111 \\ aksahidayat@polinef.id \\ bDhoto@pens.ac.id \\ cBasuki@pens.ac.id \\ d Fajrulfalah93@pasca.student.pens.ac.id
}

\begin{abstract}
At the 2018 ASEAN Games, Indonesia won 98 medals, the number of medals exceeded the expected target, this achievement could not be separated from the role of coaches who always monitor the condition of their athletes while training on the field. One of the conditions of monitoring athletes can be done by monitoring the heartbeat activity of each athlete during exercise. In this study the authors made a heart rate monitoring tool for IoT 100 meter runners that can be used in the field and send data in real time. Polar Heart Rate heart rate sensor is good to use because the data reading error is $0.4 \%$. 2 . heart rate monitoring can only communicate up to 70 meters more. Data entered and read well into the server.
\end{abstract}

Keywords—component; Internet of Things, Heart Rate Sensors, Embedded System.

\footnotetext{
Abstrak-Pada ajang olahraga ASEAN Games 2018, Indoensia meraih 98 medali, jumlah medali ini melampaui target yang diharapkan, Capaian ini tidak lepas dari peran pelatih yang selalu memantau kondisi para atletnya saat latihan di lapangan. Pemantauan kondisi atlet dapat dilakukan salah satunya dengan cara memantau aktivitas detak jantung dari setiap atlet selama melakukan latihan. Pada penelitian ini penulis membuat alat monitoring detak jantung untuk pelari 100 meter berbasis IoT yang dapat di gunakan di lapangan dan mengirim data secara real time. Sensor detak jantung Polar Heart Rate baik di gunakan dikarenakan error pembacaan data adalah $0,4 \%$. 2. monitoring detak jantung hanya dapat berkomunikasi hingga 70 meter lebih. Data masuk dan terbaca dengan baik kedalam server.
}

Kata Kunci-Komponen; Internet of Things, Heart Rate Sensors, Embedded System.

\section{Pendahuluan}

Pada ajang olahraga ASEAN Games 2018, Indoensia meraih 98 medali, jumlah medali ini melampaui target yang diharapkan, Capaian ini tidak lepas dari peran pelatih yang selalu memantau kondisi para atletnya saat latihan di lapangan. Pemantauan kondisi atlet dapat dilakukan salah satunya dengan cara memantau aktivitas detak jantung dari setiap atlet selama melakukan latihan [1]. Banyaknya detak jantung permenit seorang atlet dapat dijadikan sebagai indikator untuk mengukur kondisi kesehatannya. Semakin sering seorang atlet berlatih maka akan semakin melambat detak jantungnya. Hal ini dikarenakan otot jantung yang semakin besar sehingga jantung dapat mengalirkan lebih banyak darah setiap menitnya [2].

Salah satu indikator untuk menentukan kemampuan olahraga dapat dilakukan dengan cara memantau detak jantung olahragawan [3]. Saat ini penggunaan perangkat komersial seperti Apple Watch, Garmin, Fiblit Blaze, dan Tom Tom Spark Cardio merupakan salah satu perangkat untuk mendeteksi detak jantung namun perangkat tersebut memiliki harga yang mahal serta untuk mengakses data pada database tidak memungkinkan.

Saat ini telah ada alat untuk memantau detak jantung salah satunya adalah finger grove sensors, alat ini pernah digunakan untuk memantau detak jantung olahragawan [4]. Alat ini memiliki prinsip pembacaan detak jantung dengan menggunakan cahaya optik yang dapat membaca aliran darah pada kulit, biasanya sensor ini diletakkan pada ujung jari maupun di telinga atlet sehingga tidak 
efisien digunakan oleh atlet pada saat berlari dikarenakan sensor ini dapat lepas atau jatuh oleh ayunan tangan atlet maupun gerakan atlet yang cenderung cepat dan berulang.

Pada penelitian ini penulis membuat alat monitoring detak jantung untuk pelari 100 meter berbasis IoT yang dapat di gunakan di lapangan dan mengirim data secara real time.

\section{Metode Penelitian}

\section{A. Metode}

Pada penelitian ini penulis menggunakan waterfall model, waterfall model ini merupakan bagian dari System Life Cycle merupakan model metodologi untuk membantu dalam pengembangan sistem.

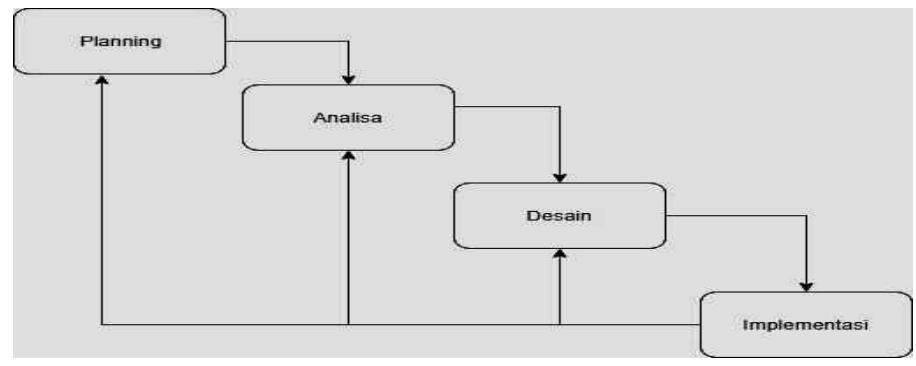

Gambar 1. Metodologi Penelitian

\section{B. Perencanaan}

Perencanaan disini merupakan tahap melihat dan penilai seperti apa yang akan dibuat, tujuan serta ruang lingkup dalam pengembangannya sehingga dapat menentukan serta mengevaluasi strategi apa yang digunakan dalam pengembangan sistem ini [5]. Pada tahap ini penulis akan membuat alat monitoring detak jantung untuk atlet lari 100 meter dengan berlandaskan pada Internet of Things. Penelitan ini akan di lakukan di lapangan atlet KONI Surabaya.

\section{Analisa}

Analisa merupakan tahap dimana peneliti mengumpulkan referensi terkait dalam pembuatan sistem[6], kebutuhan yang dibutuhkan untuk membangun sistem ini yakni Polar Transmitter, Polar Reciever, Arduino, Raspberry Pi3, Server. Sistem ini dibangun dengan skema Internet of Things.

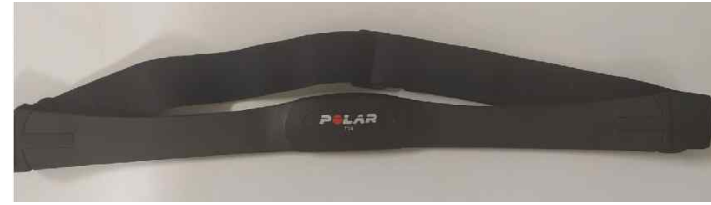

Gambar 2. Polar Transmitter

Polar Transmitter berperan untuk membaca detak jantuk, data detak jantung yang dibaca oleh sensor ini akan dikirim melalui bluetooth 4.0. Bluetooth 4.0 ini mengkomsumsi daya jauh lebih kecil dengan jarak jangkauan 100 meter dan transfer rate 1 Mbps [7]-[9]. Sistem komunikasi bluetooth ini juga banyak digunakan untuk membangun perangkat IoT [10].

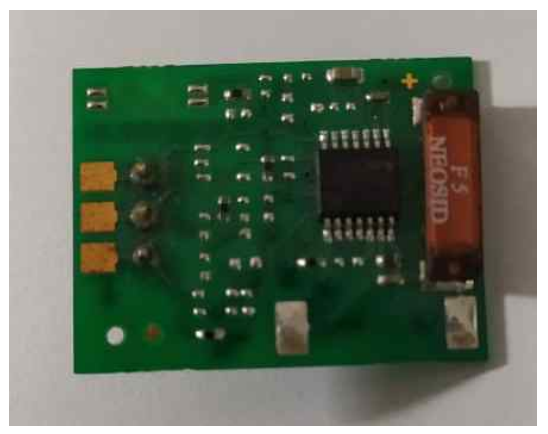

Gambar 3. Polar Reciever

Pada gambar 2, Polar Reciever berperan sebagai penerima data heart rate yang dikirimkan oleh polar transmitter

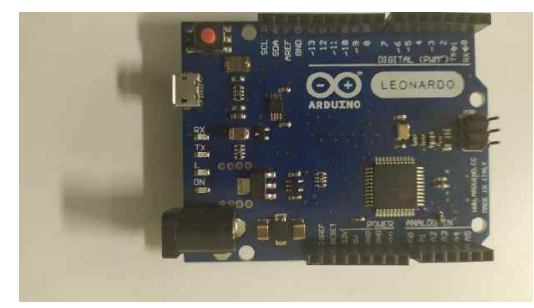

Gambar 4. Arduino

Arduino merupakan perangkat keras dengan prosesor Atmel AVR dengan bahas pemrograman yang identik dengan Program C [11], arduino berperan membaca data yang diterima oleh polar reciever dan diteruskan ke raspberry pi. 


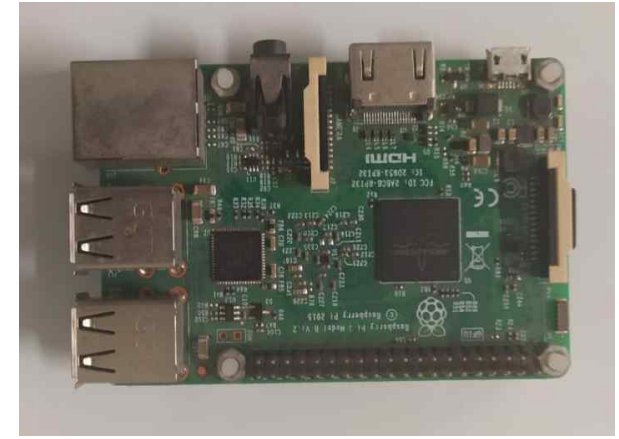

Gambar 5. Raspberry Pi.

Pada gambar 5,Raspberry Pi merupakan singleboard-circuit (SBC) yang dapat menjalankan program sebagaimana komputer [12], board ini mengandalkan penyimpanan data SD card, namun raspberry pi ini mampu melakukan komunikasi via wifi dan mampu menjalankan modem untuk koneksi 4G [13], [14]. Pada penelitian ini raspberry pi berperan mengambil data dari arduino dan mulai melakukan pembuatan file yang akan di tulis ke dalam database dan dikirimkan melalui protocol MQTT.protokol MQTT merupakan protokol yang mendukung konektifitas antara mesin dan mesin (M2M) atau Internet of Things dengan penggunaan bandwith yang rendah serta memiliki latency yang tinggi [15]. Untuk komunikasi data yang digunakan adalah jaringan 4G sehingga komuniksasi data dari board ke server datapat terjadi. Konektivitas menggunkan modem yang mengubah sinyal informasi menjadi sinyal pembawa [16].

\section{Desain System}

Dari hasil analisa bahan dan peralatan sebelumnya maka guna membangun sistem monitoring detak jantung maka dibutuhkan sebuah desain, system monitoring detak jantung untuk atlet lari 100 meter didesain seperti pada gambar 6 .

Pada Gambar 6, dapat diketahui bahwa no 1 Adalah polar transmitter, polar transmitter ini bertugas menangkap sinyal detak jantung kemudian di kirim ke no 2,yakni polar reciever yang akan mengirim data detak jantung ke arduino, arduino pada no 3 akan mengolah data yang diterima oleh reciever dan mengubah nilai datanya dari integer ke string dan diteruskan ke no 4 yakni raspberry pi yang akan melakukan pengukuran dan merecord data serta mengirimkan data ke server via modem dengan portokol MQTT. Pada proses pengiriman data Raspberry pi berperan sebagai Publish yang akan mengirim data ke Subscriber.
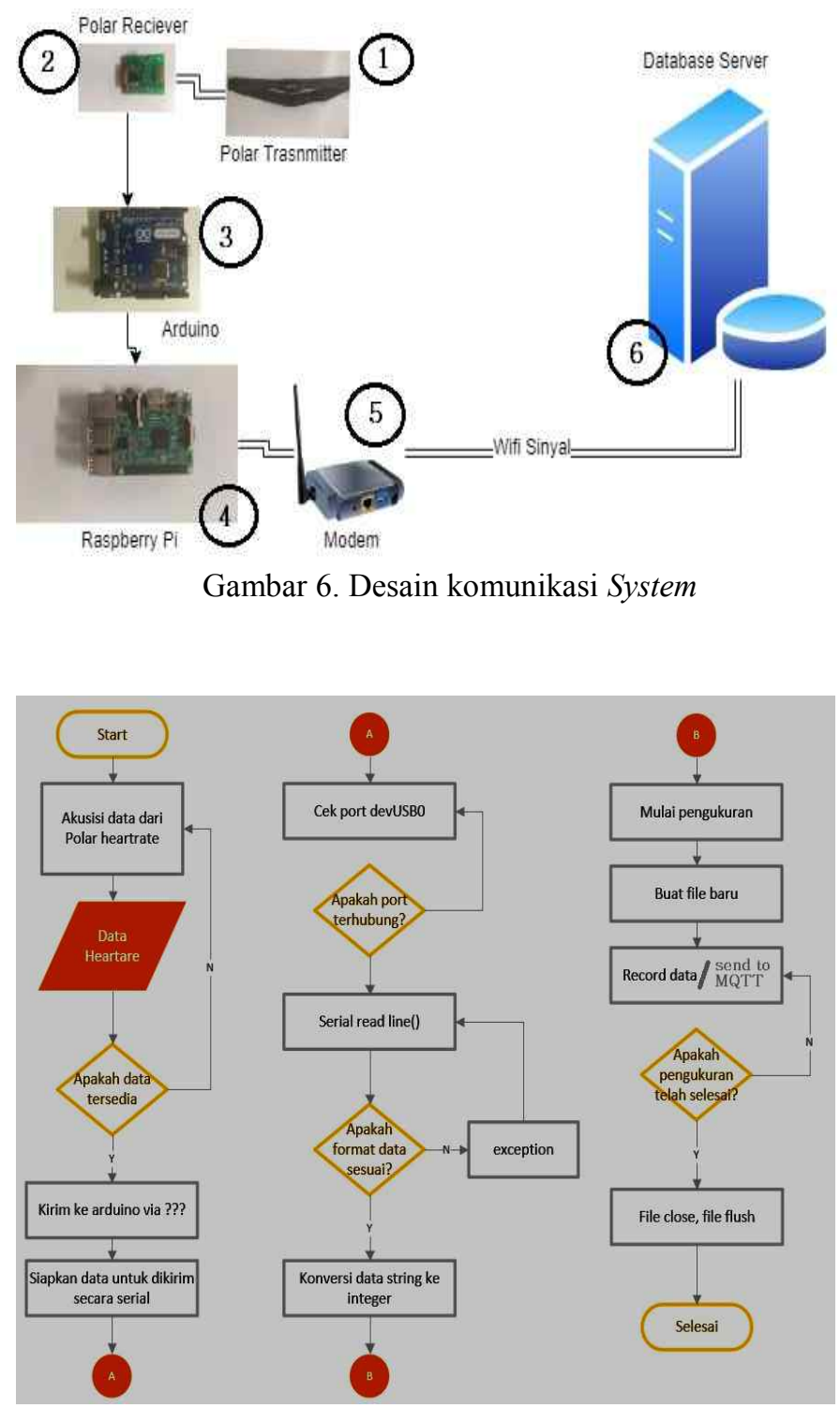

Gambar 7. Data Flow Diagram

Pada gambar 7, terlihat bahwa pertama-tama sensor akan menerima data dari polar transmitter yang dipasang pada dada atlet dikirimkan ke polar transmitter, data tersebut akan di baca oleh reciever dan jika terbaca maka akan di kirim ke arduino. Pada arduino kemudian melakukan chek port USB yang terhubung dan membaca data serial yang di terima dari reciever, data serial ini terbaca dikarenakan perhitungan denyut jantung berdasarkan beat disetiap detik. 


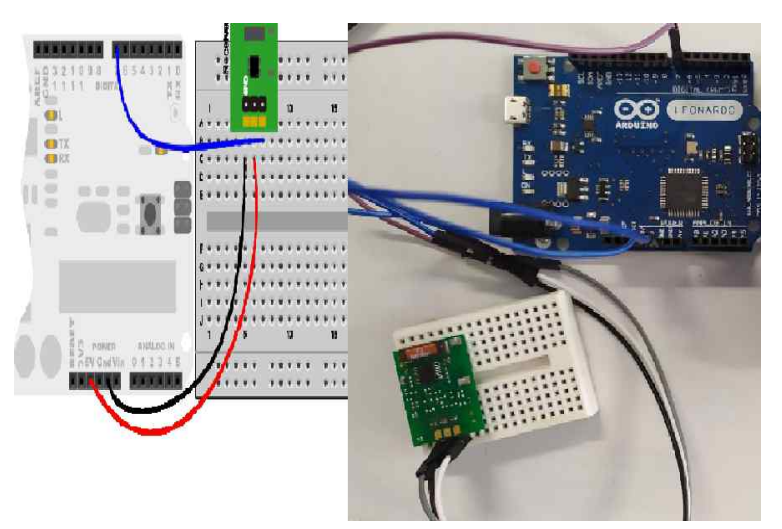

Gambar 8. Tampilan Hardware

Arduino kemudian melakukan konversi dalam bentuk angka dan dikirim ke raspberry pi, raspberry pi berfungsi sebagai kontrol untuk memulai pengukuran, menulis file yang berisi hasil rekaman dari sensor detak jantung.

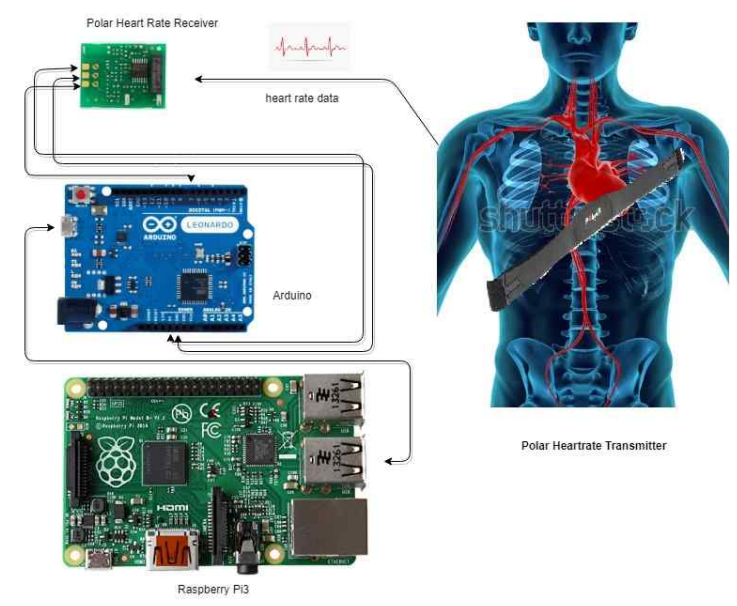

Gambar 9. Gambaran penggunaan sensor

Pada gambar 9. Sensor detak jantung diletakkan di dada dan menggunakan strap sehingga tidak jatuh atau bergeser.

\section{Hasil dan Pembahasan}

Pada penelitian ini dapat diketahui dari: (1) Kinerja pemantauan detak jantung yang telah dibuat; (2) Kinerja Sensor Polar T34; (3) Kinerja Pengiriman IoT pada Pengiriman data ke server.

\section{A. Kinerja Pemantauan detak jantung yang telah di buat}

Analisa kinerja sensor ini dengan membandingkan sensor Polar Heart rate dengan sensor detak jantung yang sejenis. Disini penulis menggunakan (1) sensor Polar T34; (2) Finger Pulse Sensor; (3) Xiaomi band.

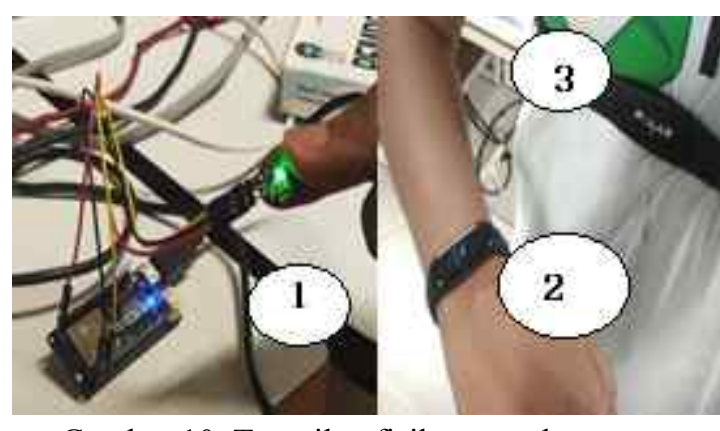

Gambar 10. Tampilan fisik sensor heart rate

Pulse Finger Sensor merupakan sensor detak jantung yang bekerja menggunakan prinsip Photoplethysmografy (PPG) yakni metode untuk mengukur detak jantung berdasarkan volume aliran darah dalam nadi yang berada sangat dengan kulit. Mi Band 3 merupakan jam tangan cerdas yang dapat menangkap detak jantung dengan prinsip PPG [17], [18].

Tabel 1. Hasil Perbandingan Kinerja Sensor Detak Jantung

\begin{tabular}{|c|c|c|c|c|c|c|}
\hline No & Sample & Umur & $\begin{array}{c}\text { PolarT34 } \\
\text { (bpm) }\end{array}$ & $\begin{array}{c}\text { Finger } \\
\text { Pulse } \\
\text { Sensor } \\
\text { (bpm) }\end{array}$ & $\begin{array}{c}\text { Xiami } \\
\text { Band } \\
\text { (bpm) }\end{array}$ & $\begin{array}{c}\text { Error } \\
\mathbf{( \% )}\end{array}$ \\
\hline 1 & $\mathrm{~A}(\mathrm{~L})$ & 25 & 98 & 97 & 98 & 1 \\
\hline 2 & $\mathrm{~B}(\mathrm{~L})$ & 27 & 92 & 92 & 92 & 0 \\
\hline 3 & $\mathrm{C}(\mathrm{L})$ & 27 & 91 & 90 & 90 & 2 \\
\hline 4 & $\mathrm{D}(\mathrm{L})$ & 32 & 91 & 91 & 90 & 1 \\
\hline 5 & $\mathrm{E}(\mathrm{L})$ & 21 & 72 & 72 & 72 & 0 \\
\hline 6 & $\mathrm{~F}(\mathrm{~L})$ & 22 & 77 & 77 & 77 & 0 \\
\hline \multicolumn{7}{|c|}{ Rata-Rata } \\
\hline
\end{tabular}

Pada tabel 1. kinerja dari sensor polarT34,pulse sensor , dan xiaomi mi band 3, rata-rata kesalahan yang didapatkan hanya $0.4 \%$.

Tabel 2. Uji coba jarak transfer data sensor.

\begin{tabular}{ccc}
\hline No & Range & Status \\
\hline 1 & $10-15$ meters & Read \\
2 & $16-25$ meters & Read \\
3 & $26-30$ meters & Read \\
4 & $31-40$ meters & Read \\
5 & $41-55$ meters & Read \\
6 & $55-60$ meters & Read \\
7 & $61-70$ meters & Read,Lost \\
8 & $71+$ & Lost \\
\hline
\end{tabular}


Pada tahap ini sebelum peneliti mengambil data langsung di lapangan peneliti telah melakukan uji coba bagaimana jika Heartrate Sensor monitoring di gunakan dengan jarak yang berbeda. Uji coba ini dilakukan untuk mengetahui sejauh mana sensor Heartrate ini dapat mengirim data. Diperoleh pada jarak maksimal 71 meter sensor ini kehilangan komunikasi sehingga alat ini tepat digunakan untuk cabang olahraga lari 100 meter dengan cara alat deteksi detak jantung ini diletakkan di tengah lintasan jarak 50 meter dari start dan 50 meter dari finish.

\section{B. Kinerja Sensor Polar}

Pada penelitian ini kami melakukan implementasi faktual di Lapangan atlet KONI yang terletak di kampus Universitas Negeri Surabaya (UNESA) pada Fakultas Ilmu Keolahragaan (FIK) yang terdiri dari 10 partisipan Athlet lari 100 meter berasal dari Komite Olahraga Nasional Indonesia (KONI) yang berlokasi di UNESA Jl. Lidah Wetan. 10 Athlet ini di asramakan oleh KONI dan melakukan latihan secara intensif setiap harinya sesuai panduan dan arahan dari pelatih, Serta 10 partisipan non athlet di Kampus Politeknik Elektronika Negeri Surabaya (PENS) yang terdiri dari 4 Mahasiswa Departemen Teknik Komputer, 4 Mahasiswa Pascasarjana dan 2 Mahasiswa Multimedia Broadcasting (MMB). Implemntasi ini dilakukan dengan menggunkan sensor heart rate. Prosedure implementasi ini yakni data di ambil sebelum atlet/non atlet melakukan aktifitas, pada saat lari dan beristirahat. pengambilan sample dilakukan dengan total sampling, sehingga didapatlkan jumlah sample yang akan direcord adalah 20 orang dengan atlet pelari profesional berjumlah 7 orang, pelari junior atletik 3 orang dan non atlete 10 orang.

Tabel 3. Peserta Atlet dan Non Atlet

\begin{tabular}{|c|c|c|c|c|c|c|c|c|c|c|}
\hline \multirow[b]{2}{*}{ Var } & \multicolumn{7}{|c|}{ Usia } & \multirow[b]{2}{*}{ RT } & \multicolumn{2}{|c|}{ tp } \\
\hline & 16 & 17 & 18 & 19 & 20 & 21 & 22 & & $\begin{array}{l}\text { s } \\
\text { m } \\
\text { a }\end{array}$ & pt \\
\hline $\begin{array}{c}\text { Atlete Lari } \\
\text { Profesional } \\
n=10\end{array}$ & 0 & 2 & 1 & 0 & 0 & 0 & 7 & 20.06 & 3 & 7 \\
\hline $\begin{array}{c}\text { Non Atlet } \\
\text { (Mahasiswa } \\
\text { ) } n=10\end{array}$ & 0 & 0 & 0 & 0 & 0 & 3 & 7 & 21.07 & 0 & 10 \\
\hline
\end{tabular}

Data yang diambil meliputi 3 hal, yaitu denyut jantung sebelum berlari (istirahat), pada saat berlari, dan waktu pemulihan. Denyut jantung sebelum berlari di lakukan di pagi hari sebelum para atlete melakukan pemanasan dan melakukan kegiatan, data denyut jantung akan dicatat oleh sensor selama 5 menit.
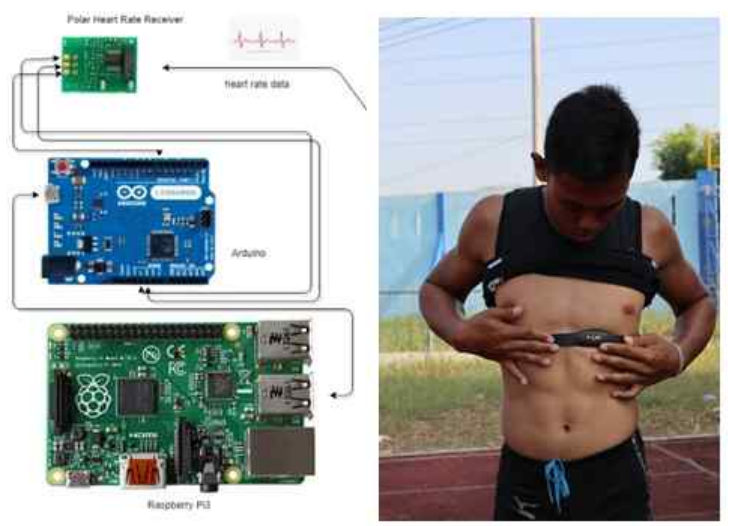

Gambar 11. Implementasi sensor.

Selanjutnya dilakukan pengambilan data ketika atlet berlari dilapangan, dan ketika atlet selesai berlari, pengambilan data atlet dilakukan persesi setiap peserta diambil datanya sebelum olahraga, ketika olahraga dan ketika istirahat dilakukan dalam 1 sesi per atlet setelah itu giliran atlet berikutnya.

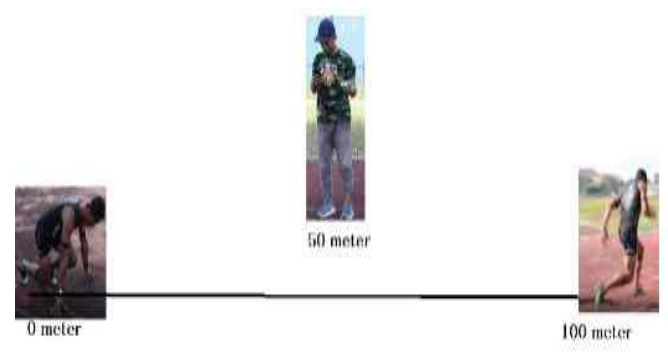

Gambar 11. Scenario Pengambilan Data dan Implementasi.

Hasil record data heartrate adalah hasil perekaman detak jantung atlet langsung dilapangan dengan jumlah sample 10 orang atlet dan 10 orang non atlet, record data heartrate ini dilakukan saat sebelum olahraga, sedang berlari, dan setelah berlari. 


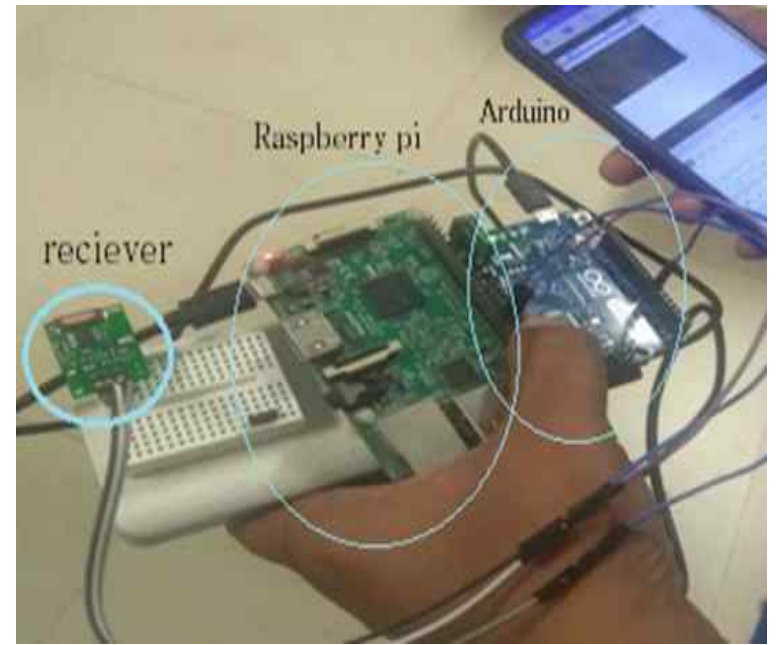

Gambar 12. Tampilan Fisik Pemantauan Detak Jantung

Gambar 12, menunjukkan tampilan fisik alat yang digunakan untuk mengukur kemampuan detak jantung, yang dikontrol dengan menggunakan smartphone dikarenakan raspberry mempunyai vitur VNC yang memungkinkan menduplikasi tampilan desktop dengan menggunakan jaringan wifi.

\section{Heart Rate Sebelum Olahraga}

Setelah merekord data atlet dan non atlet menggunakan sensor pemantauan detak jantung maka diperoleh grafik seperti pada gambar 12. data tersebut berasal dari 10 orang atlete dan 10 orang non atlet dengan jumlah Heartrate ketika sedang istirahat sebelum berolahraga.

\begin{tabular}{l}
-AT1 OAT2 \\
-AT4 \\
\hline 0
\end{tabular}

Gambar 12. Heart Rate Sebelum Olahraga

Pada gambar 12, dapat diketahui bahwa Heartrate pada Atlet cenderung lebih rendah dari pada heartrate non athlete ini disebabkan oleh intensitas latihan juga mempengaruhi ruang pada jantung sehingga volume darah yang dipompa keseluruh tubuh meningkat.

\section{Heart Ketika Berlari 100 Meter.}

Pada saat olahraga seorang atlet akan mengalami kenaikan detak jantung dikarenakan kegiatan fisik, dapat kita ketahui atlet mengalami peningkatan detak jantung secara signifikan dari $60 \mathrm{bpm}$ meningkat hingga 120 bpm seperti pada gambar 24 kenaikan denyut jantung ini dipicu adanya aktifitas fisik yang dilakukan oleh partisipan,

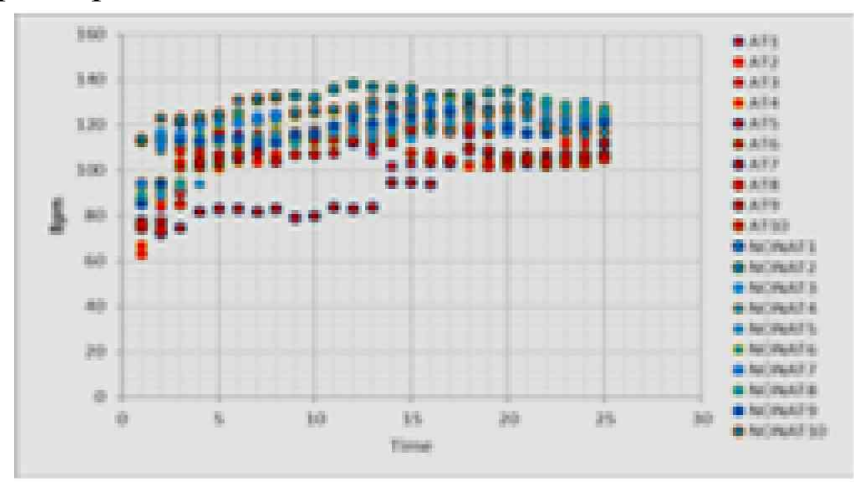

Gambar 13. Heart Rate Saat berlari 100 meter.

Pada gambar 13 dapat dilihat bahwa rerata detak jantung atlet ketika melakukan aktifitas fisik berada pada 100 bpm namun pada non atlet cenderung lebih tinggi pada 130-140 bpm.

\section{E. Heart Ketika Beristirahat.}

Ketika beristirahat setelah berolahraga maka detak jantung atlet juga mengalami penurunan dan menuju ke titik normal seiring dengan waktu.

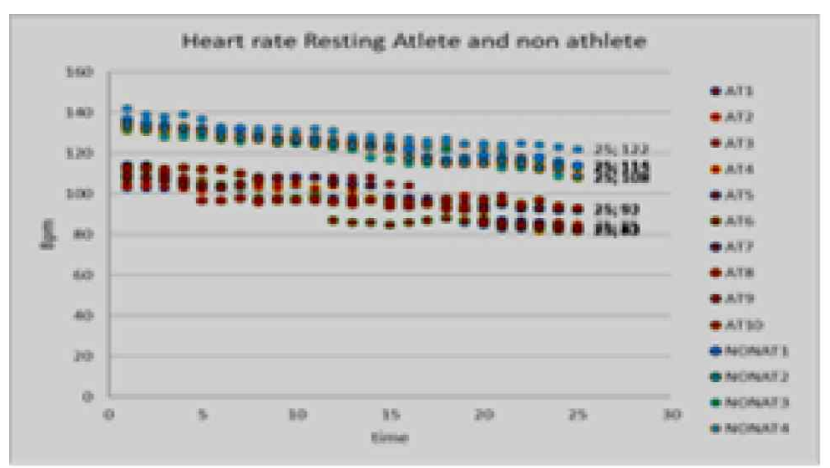

Gambar 14. Heart Rate Resting Atlet and Non Atlet

Melihat dan memperhatikan penyebaran data detak jantung athlete dan non athlete ketika sebelum olahraga, olahraga dan beristirahat pada Gambar 12 hingga 14 . Maka dapat disimpulkan bahwa athlete memiliki detak jantung yang lebih rendah dari pada non athlete kisaran 
45-62 Bpm ketika beritirahat. Dan ketika berlari athlete mampu menaikkan detak jantungnya dengan signifikan namun cenderung stabil hal tersebut berguna untuk mendapatkan kecepatan dan power diawal lari ,dikarenakan berlari untuk jarak 100 meter dibutuhkan kecepatan dan kekuatan di start awal.

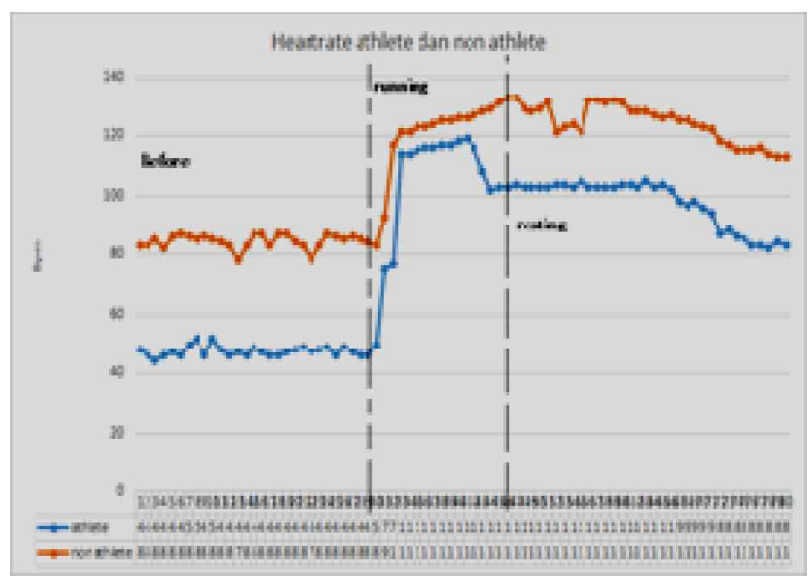

Gambar 15. Perbandingan Heartrate Atlet dan Non Atlet

\section{F. Kinerja Pengiriman Data Ke Server.}

Data heartrate dari sensor dikirim ke system dan diteruskan ke database dengan menggunakan MQTT. Grafana adalah sebuah dashboard yang digunakan untuk melakukan visualisasi data secara real-time dari data yang berasal dari sensor heart rate. Setelah data masuk ke MQTT broker dan disimpan pada influxDB, grafana akan melakukan query pada influxDB secara berkala sesuai pengaturan refresh rate pada dashboard.

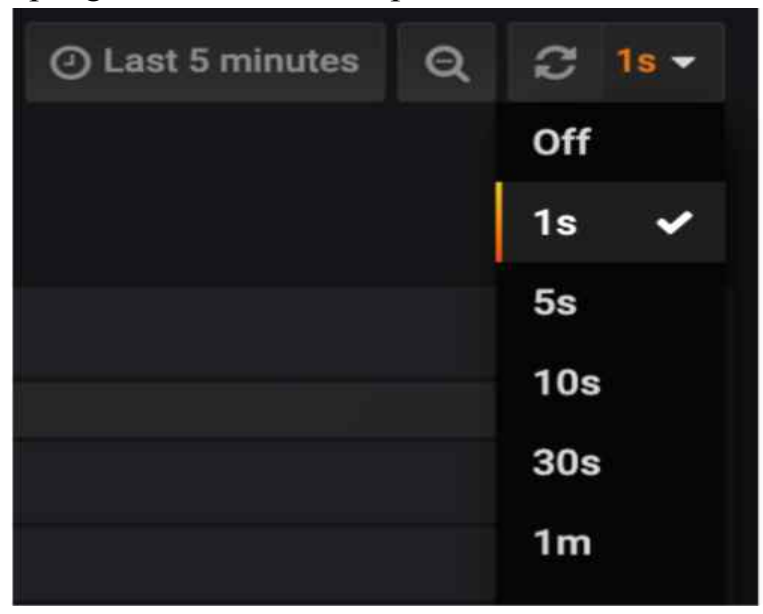

Gambar 16. Pengaturan Refresh Rate Grafana.

Data heartrate dari sensor dikirim ke system dan diteruskan ke database dengan menggunakan MQTT.
Grafana adalah sebuah dashboard yang digunakan untuk melakukan visualisasi data secara real-time dari data yang berasal dari sensor heart rate. Setelah data masuk ke MQTT broker dan disimpan pada influxDB, grafana akan melakukan query pada influxDB secara berkala sesuai pengaturan refresh rate pada dashboard.

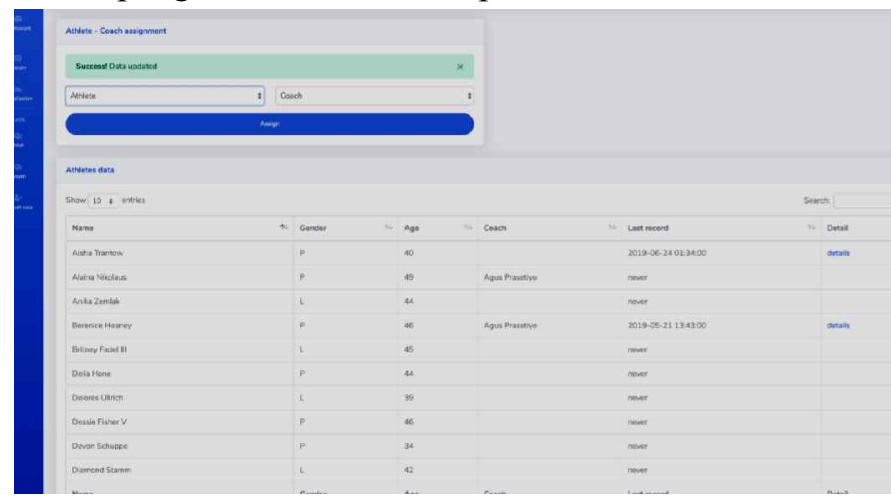

Gambar 17. Tampilan Website Monitoring detak jantung.

Pada halaman dashboard, ditampilkan ringkasan jumlah data yang terdaftar dalam database. Pada halaman ini juga terdapat fitur untuk melakukan Fetch/Syncronization data dari server cloud wearnotch. Ketika tombol Sync data di klik maka web akan melakukan update value pada key "DO_FETCH" redis menjadi 1 , yang mana ini akan memberitahu aplikasi trigger untuk menjalankan tugasnya.

\section{Kesimpulan}

Kesimpulan dari penelitian ini adalah:

1. Sensor detak jantung Polar Heart Rate baik di gunakan dikarenakan error pembacaan data adalah $0,4 \%$.

2. monitoring detak jantung hanya dapat berkomunikasi hingga 70 meter lebih, sehingga hanya dapat di gunakan pada cabang olah raga 100 meter dengan meletakkan penerima di tengah lintasan.

3. Data masuk dan terbaca dengan baik kedalam server

\section{Ucapan Terima Kasih}

Terima kasih banyak kepada Pihak PENS yang telah membantu dan membimbing dalam terselesaikannya Penelitian ini, dan juga terima kasih 
banyak kepada Pihak KONI SURABAYA yang telah mengijinkan sehingga memudahkan penulis untuk mengimplementasikan dan menguji coba alat yang telah dibuat.

\section{Daftar Pustaka}

[1] F. S. Martinelli et al., "Heart rate variability in athletes and nonathletes at rest and during head-up tilt," Brazilian $J$. Med. Biol. Res., vol. 38, no. 4, pp. 639-647, 2005.

[2] D. J. Plews, P. B. Laursen, A. E. Kilding, and M. Buchheit, "Heart rate variability in elite triathletes, is variation in variability the key to effective training A case comparison," Eur. J. Appl. Physiol., 2012.

[3] A. E. Aubert, B. Seps, and F. Beckers, Heart Rate Variability in Athletes, vol. 33, no. 12. 2003.

[4] I. Puspasari and P. Susanto, "Monitoring Target Heart Rate (THR) for Optimization," vol. 2, pp. 87-94, 2018.

[5] Husson University, "What is the software development life cycle?," Husson University, 2019. .

[6] A. Singh and P. J. Kaur, "Analysis of software development life cycle models," in Lecture Notes in Electrical Engineering, 2019.

[7] S. M. Darroudi and C. Gomez, "Bluetooth low energy mesh networks: A survey,” Sensors (Switzerland). 2017.

[8] K. B. G. Anil, K. C. Bhagyalakshmi, K. Lavanya, and K. H. Gowranga, "A bluetooth low energy based beacon system for smart short range surveillance," in 2016 IEEE International Conference on Recent Trends in Electronics, Information and Communication Technology, RTEICT 2016 - Proceedings, 2017.

[9] M. Castillo-Cara, E. Huaranga-Junco, G. Mondragón-Ruiz, A. Salazar, L. O. Barbosa, and E. A. Antúnez, "Ray: Smart
Indoor/Outdoor Routes for the Blind Using Bluetooth 4.0 BLE," in Procedia Computer Science, 2016.

[10] S. Raza, P. Misra, Z. He, and T. Voigt, "Building the Internet of Things with bluetooth smart," Ad Hoc Networks, 2017.

[11] T. Pan, Y. Zhu, T. Pan, and Y. Zhu, "Getting Started with Arduino," in Designing Embedded Systems with Arduino, 2017.

[12] R. P. Foundation, "What is a Raspberry Pi?," Raspberry Pi. 2015.

[13] C. Bell, Beginning sensor networks with Arduino and Raspberry Pi. 2013.

[14] V. Vujović and M. Maksimović, "Raspberry Pi as a Wireless Sensor node: Performances and constraints," in 2014 37th International Convention on Information and Communication Technology, Electronics and Microelectronics, MIPRO 2014 - Proceedings, 2014.

[15] D. Soni and A. Makwana, "A survey on mqtt: a protocol of internet of things(IoT)," Int. Conf. Telecommun. Power Anal. Comput. Tech. (Ictpact - 2017), no. April, pp. 0-5, 2017.

[16] J. Byun, B. W. Kim, C. Y. Ko, and J. W. Byun, "4G LTE network access system and pricing model for IoT MVNOs: spreading smart tourism," Multimed. Tools Appl., 2017.

[17] M. Li and Y. T. Kim, "Design of a wireless sensor system with the algorithms of heart rate and agility index for athlete evaluation," Sensors (Switzerland), vol. 17, no. 10, 2017.

[18] H. K. Ra, J. Ahn, H. J. Yoon, J. Ko, and S. H. Son, "Accurately Measuring Heartrate Using Smart Watch," in Proceedings - 2016 IEEE 22nd International Conference on Embedded and Real-Time Computing Systems and Applications, RTCSA 2016, 2016. 